\title{
Aspects of adapting the cooling installation in a food cold storage system to the applicable f-gas regulations
}

\author{
Filip BRAŃSKI ${ }^{1}$ and Adam RUCIŃSKI*1 \\ ${ }^{1}$ Faculty of Power and Aeronautical Engineering, Warsaw University of Technology, Warsaw, Poland
}

\begin{abstract}
The paper presents the methodology of the analysis of the cooling system reconstruction in a food cold store under the regulations applicable from the beginning of 2020. They result from the so-called the F-Gas Act concerns the use of refrigerants with a low environmental impact. First, the elements of the existing regulations on the use of refrigerants were discussed. This part of article focus mainly on the F-Gas Act and the regulations it entails. Then, the refrigerants used so far in refrigeration systems were compared with substitutes, which were the only ones that have been approved for use since 2020, thanks to the low GWP index. Their properties are briefly described, along with the benefits (primarily for the environment) of their use. The main part of the work is the analysis of the reconstruction of the cooling system to use an alternative refrigerant. During the work, the construction of the cold storage was analyzed together with the system currently working in analysed location. Then, the heat balance was calculated, thanks to which it was possible to determine the demand for cold. Than, several refrigerants that meet the latest standards and application regulations were selected. Their operating parameters were examined, the possible variants of use were compared in relation to the determined demand for cooling and the most important operational features were summarized.
\end{abstract}

Keywords: cold store, cooling installation, F-Gas Act, refrigerant.

\section{Introduction}

Currently, it is difficult to visualize everyday functioning without refrigeration and air conditioning. Systematically raised standard of living strongly influences the intensive development of these industry market [17]. However, cooling requires the use of a medium in the form of a refrigerant, which unfortunately is often not environmentally friendly $[15,16,33]$.

Following the global trends, it can be seen that the developing direction in the refrigeration industry is the transition into the use of ecological refrigerants $[7,37]$. Of course, this is usually the case when it is technically and economically justified - (not so, as it is a requirement and therefore both equipment manufacturers and users must technically comply with the legal guidelines under the Montreal Protocol) [28]. Alternative substitutes are starting to play an important role in the refrigeration industry, where trends are constantly moving towards new, low GWP substances with a low environmental impact $[6,14,17,44]$. It can be seen that, in line with the European Union's strategy and numerous global regulations limiting the use of fluorinated greenhouse gases, the direction of replacing refrigerants with more environmentally friendly ones is only a matter of time [11, 38, 39, 43]. Such limitations mean that a very difficult challenge has been presented to all owners and users of existing refrigeration installations, which until now operated on conventional refrigerants. Their task is to adapt the operating HVACR installations to the new applicable regulations. This is mainly related to the replacement of the refrigerant with an ecological alternative, which is rarely suitable for replacing those working in existing systems. Alternative refrigerants are usually used in new, specially designed installations, which, unfortunately, can lead to a complete rebuilding of the systems that have been working so far $[3,20]$. It is important to consider, among others, when choosing environmentally friendly refrigerants $[2,24]$. Their operating pressures, performance, energy efficiency, ease of use, installation, service and maintenance, as well as safety (including toxicity, flammability and high pressure) and environmental impact (zero ODP and minimum

*Corresponding author: E-mail address: (adam.rucinski@pw.edu.pl) Adam RUCIŃSKI

https://doi.org/10.37105/iboa.111

Received 1 May 2021

Available online 30 June 2021

ISSN 2450-1859, eISSN 2450-872

Published by Centrum Rzeczoznawstwa Budowlanego 
GWP). Also important are the economic issues (investment and operating cost) and availability of the refrigerant [1, $4,8,9,12,13,23,25,27,32,34,36,42]$.

\section{Polish F-Gas regulations}

Polish law was adapted to Regulation (EU) No 517/2014 of the European Parliament and of the Council by the national Act of 12 July 2017 amending the Act on substances that deplete the ozone layer and on certain fluorinated greenhouse gases and certain other acts $[11,39]$. The regulation established a mechanism for the systematic reduction of the total amount of HFCs (expressed in tonnes of $\mathrm{CO} 2$ equivalent) placed on the market in the European Union. Figure 1 shows the process of limiting the use of F-gases substances over the next several years.

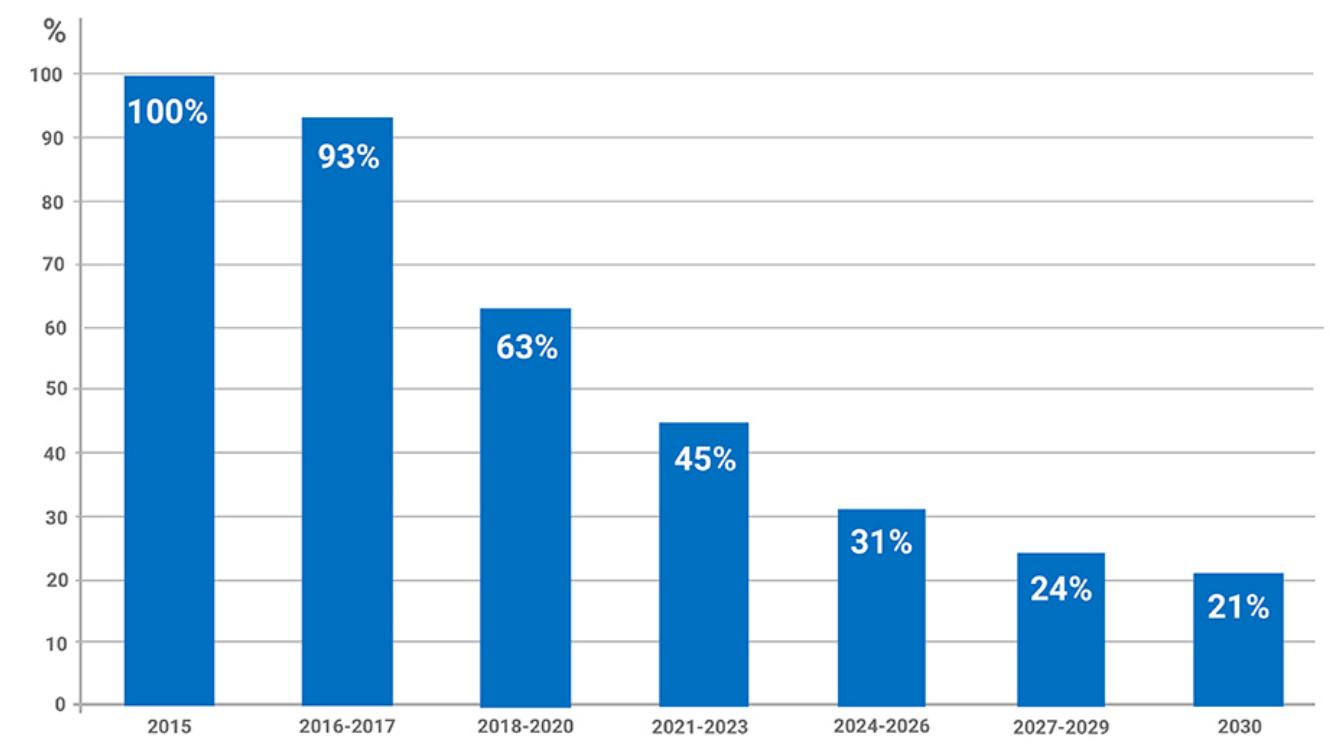

Figure 1. Annual HFC consumption reduction - compared to 2015 level (100\%) [21]

HFC refrigerants are covered by the so-called phase down scenario, which is already in force on January 1, 2015. According to this, there is a gradual reduction of the total amount of the indicated substances that can be placed on the market per year [18]. Figure 1 refers to the average amount of HFCs calculated from 2009 to 2012, produced or marketed in the EU, which is equivalent to emissions of 183 million tonnes of $\mathrm{CO} 2$ per year. During the periods presented in the Figure 1, it is possible to produce a correspondingly lower limit calculated by the CO2 equivalent. It is expected that by reducing the authorized quantities of fluorinated gases on the market, their prices will rise significantly, which will weaken the market position of the substances concerned.

Along with the F-Gas Act, other provisions contained in Regulation (EU) No. 517/2014 also entered into force. One of them is the initiation of restrictions and bans on placing on the market refrigeration equipment compatible with HFC refrigerants with too high GWP (table 1). This is because F-gases include virtually all currently used refrigerants for refrigeration and air conditioning equipment. With the arrival of certain deadlines in the Regulation, the use of some of them becomes completely banned and the costs of others may increase significantly due to the introduction of the phase down scenario.

Another important provision is the introduction of new conditions for servicing refrigeration systems. From January 1,2020 , the use of new fluorinated greenhouse gases with a GWP of 2,500 or greater in servicing or maintaining existing refrigeration installations with a charge of 40 tonnes of $\mathrm{CO} 2$ equivalent or greater is totally prohibited. The exception is the recovery of the refrigerant until 2030 and the operation of military equipment and equipment designed to cool products to temperatures below $-50^{\circ} \mathrm{C}$.

In addition to the aforementioned direct prohibitions, the prescribed leakage checks are new. They define the statutory recommended frequency of leak checks in refrigeration and air conditioning systems. Under the provisions, the user is responsible for the inspection and up-to-date documentation of the refrigeration plant and equipment. 
Table 1. Direct restrictions and prohibitions on placing new installations on the market

\begin{tabular}{|c|c|c|}
\hline Cut-off date & Applies to & $\begin{array}{l}\text { Maximum permitted } \\
\text { GWP value }\end{array}$ \\
\hline 01.01 .2015 & Domestic refrigerators and freezers & 150 \\
\hline 01.01 .2020 & $\begin{array}{l}\text { Refrigerators and freezers for commercial } \\
\text { use (hermetically sealed equipment) }\end{array}$ & 2500 \\
\hline 01.01 .2022 & $\begin{array}{c}\text { Refrigerators and freezers for commercial } \\
\text { use (hermetically sealed equipment) }\end{array}$ & 150 \\
\hline 01.01 .2020 & $\begin{array}{c}\text { Stationary refrigeration equipment } \\
\text { (except equipment intended } \\
\text { for applications designed to } \\
\text { cool products to temperatures below }-50^{\circ} \mathrm{C} \text { ), e.g. supermarket } \\
\text { refrigeration systems or } \\
\text { cold stores }\end{array}$ & 2500 \\
\hline 01.01 .2020 & $\begin{array}{c}\text { Portable refrigeration equipment, e.g. room air conditioning } \\
\text { equipment (hermetically sealed) }\end{array}$ & 150 \\
\hline 01.01 .2022 & $\begin{array}{c}\text { Multi-piece centralized refrigeration equipment } \\
\text { with a rated capacity of } 40 \mathrm{~kW} \text { and } \\
\text { above, e.g. in supermarket installations }\end{array}$ & 150 \\
\hline 01.01 .2025 & $\begin{array}{l}\text { Split air conditioners, e.g. for domestic use } \\
\text { (refrigerant capacity less than } 3 \mathrm{~kg} \text { ) }\end{array}$ & 750 \\
\hline
\end{tabular}

The frequency of testing depends on the refrigerant capacity of the installation multiplied by its GWP, i.e. the equivalent capacity of $\mathrm{CO} 2$. In addition, the regulation also indicates the precautions necessary to limit the emissions of fluorinated greenhouse gases during the production, transport and storage of HFC gases [26].

\section{Analysis of the tested refrigeration system operating in the cold store}

As part of the analysis, exiting cold store will be examined, where the reconstruction of the cooling system is considered to work with a new refrigerant that meets the latest GWP limit standards [35, 40, 41]. Several refrigerants that could potentially replace the currently used ones were selected. Thanks to the variant analysis, the advantages and disadvantages of the indicated factors were compared in terms of operation in the required conditions and individual characteristics $[5,10,22,45]$.

\subsection{Cold store specification}

The analyzed cold store has an area of $65.63 \mathrm{~m}^{2}$ and volume of $203.44 \mathrm{~m}^{3}$. The temperature of the goods inside cold store is kept around $4^{\circ} \mathrm{C}$. On the eastern side, the cold store is adjacent to the brewery's brewhouse, with an average air temperature of $30^{\circ} \mathrm{C}$. On the rest sides, the cold store is adjacent to the utility rooms (also through the ceiling and the floor). The average temperature in such rooms is equal to $20^{\circ} \mathrm{C}$. In figure 2 there is shown the cold store schema.

Specification of the cold store:

- the heat transfer coefficient for all building wall is equal $0.2 \mathrm{~W} /\left(\mathrm{m}^{2} \cdot K\right)$;

- The cold store has no windows, as it is located in the inner part of the building, therefore the heat transfer through building partitions takes place only between the cooled surface and other rooms in the building;

- there are 3 doors leading to the cold store:

- the door on the south side serves as an emergency exit, so the analysis assumes that it is not opened;

- the door on the north side is the elevator door through which the goods are delivered to the cold store. Their dimensions are $2 \times 2 \mathrm{~m}$. Due to the fact that the door is opened only for deliveries of ordered products, the total time of opening the door during the day was assumed using the average number of deliveries per year and was calculated as $0.5 \mathrm{~min} /$ day, what is equal to $0.008 \mathrm{~h} /$ day; 


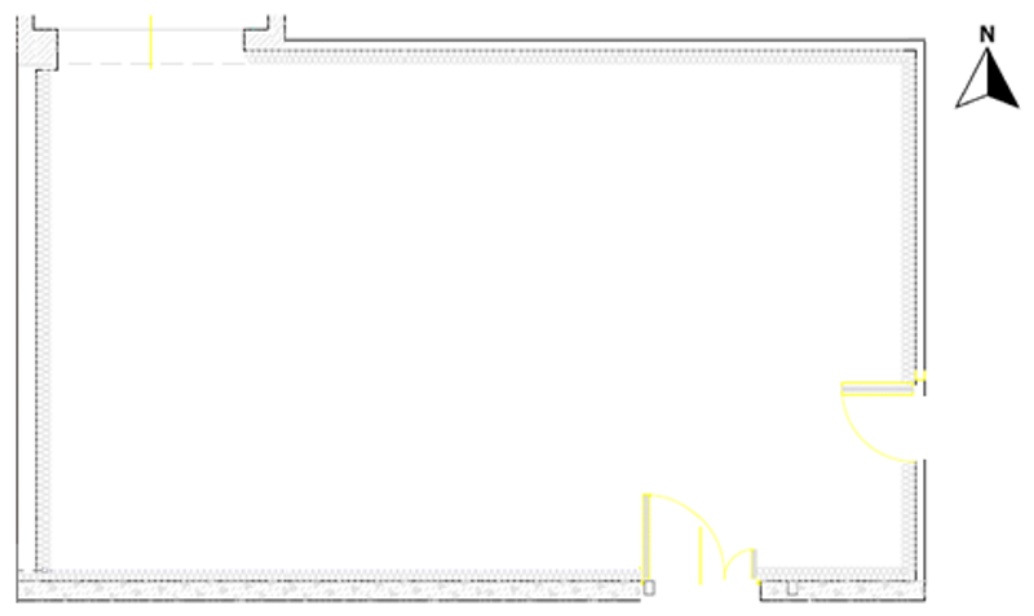

Figure 2. Diagram of the cold store

- the eastern door leads to the brewhouse and this is where traffic is most frequent during the day. Their dimensions are $1 \times 2 \mathrm{~m}$. The total time of door opening during the day was assumed as $0.5 \mathrm{~h} / \mathrm{day}$.

The table 2 shows the assumed and calculated environmental conditions inside the cold store and surrounding rooms. And the table 3 shows information about stored goods.

Table 2. Environmental conditions

\begin{tabular}{|c|c|c|}
\hline Property & Value & Unit \\
\hline $\begin{array}{c}\text { Cold storage temperature } \\
\begin{array}{c}\text { Temperature in surrounding rooms } \\
\text { (except the brewhouse) }\end{array}\end{array}$ & 20 & ${ }^{\circ} \mathrm{C}$ \\
\hline $\begin{array}{c}\text { Temperature in } \\
\text { the brewhouse }\end{array}$ & 30 & ${ }^{\circ} \mathrm{C}$ \\
\hline Air density in the cold store $\left(\right.$ at $\left.4^{\circ} \mathrm{C}\right)$ & 1.258 & $\mathrm{~kg} / \mathrm{m}^{3}$ \\
\hline Air density in surrounding rooms $\left(\right.$ at $\left.20^{\circ} \mathrm{C}\right)$ & 1.189 & $\mathrm{~kg} / \mathrm{m}^{3}$ \\
\hline Air density in the brewhouse $\left(\right.$ at $\left.30^{\circ} \mathrm{C}\right)$ & 1.150 & $\mathrm{~kg} / \mathrm{m}^{3}$ \\
\hline Air enthalpy in the cold store $\left(\right.$ at $\left.4^{\circ} \mathrm{C}\right)$ & 4.03 & $\mathrm{~kJ} / \mathrm{kg}$ \\
\hline Air enthalpy in surrounding rooms $\left(\right.$ at $\left.20^{\circ} \mathrm{C}\right)$ & 20.12 & $\mathrm{~kJ} / \mathrm{kg}$ \\
\hline Air enthalpy in the brewhouse $\left(\right.$ at $\left.30^{\circ} \mathrm{C}\right)$ & 30.19 & $\mathrm{~kJ} / \mathrm{kg}$ \\
\hline Ventilation air stream & 6 & $\mathrm{~m}^{3} /\left(\mathrm{h} \cdot \mathrm{m}^{2}\right)$ \\
\hline
\end{tabular}

The temperature of the goods delivered to the cold store is usually at room temperature, ie approx. $20^{\circ} \mathrm{C}$. The average quantity of goods requiring cooling to $4^{\circ} \mathrm{C}$ is approx. $4,500 \mathrm{~kg}$, which is due to the size of deliveries. It is expected that it will be cooled to the indicated temperature within no more than 6 hours. In order to achieve this and maintain constant parameters in the room, the working time of the refrigerating device should be at least 8 hours per day. 
Table 3. Stored goods properties

\begin{tabular}{|c|c|c|}
\hline Property & Value & Unit \\
\hline $\begin{array}{c}\text { The temperature of the goods } \\
\text { at the entrance to the cold store }\end{array}$ & 20 & ${ }^{o} \mathrm{C}$ \\
\hline $\begin{array}{c}\text { Average specific heat } \\
\text { of the cooled goods }\end{array}$ & 2.1 & $\mathrm{~kJ} /(\mathrm{kg} \cdot \mathrm{K})$ \\
\hline $\begin{array}{c}\text { Maximum quantity } \\
\text { of goods }\end{array}$ & 4,500 & $\mathrm{~kg}$ \\
\hline $\begin{array}{c}\text { The required time for } \\
\left.\text { cooling the products to } 4^{\circ} \mathrm{C}\right)\end{array}$ & 6 & $\mathrm{~h}$ \\
\hline $\begin{array}{c}\text { Working time of the cooling } \\
\text { device during the day }\end{array}$ & 8 & $\mathrm{~h}$ \\
\hline
\end{tabular}

\subsubsection{Cooling load}

Table 4 shows a summary of the heat gains calculated for the cold storage. The greatest heat gains come from the refrigerated goods. Based on the calculations, total heat gains of $12.309 \mathrm{~kW}$ were obtained.

Table 4. Cooling load of the analysed cold storage

\begin{tabular}{|c|c|}
\hline Heat gains & value $[\mathrm{kW}]$ \\
\hline heat flow through the walls & 2.373 \\
\hline $\begin{array}{c}\text { heat flux for cooling } \\
\text { the goods }\end{array}$ & 7.000 \\
\hline $\begin{array}{c}\text { heat flux for cooling } \\
\text { the infiltrated air }\end{array}$ & 0.844 \\
\hline $\begin{array}{c}\text { heat flux for cooling } \\
\text { the ventilated air }\end{array}$ & 2.092 \\
\hline Total cooling load & 12.309 \\
\hline
\end{tabular}

\section{Analysis of the use of alternative refrigerants in an existing installation}

The current installation uses R407C refrigerant. Due to the high GWP, it can no longer be used in new installations from 2020. As a result, it will be more and more difficult to find this refigerant from year to year, and it will be more and more expensive. Therefore, it was decided to replace the refrigerant with a different one. For the analysis, it was decided to use the following refrigerants [19, 29-31]:

- Option 1 (Baseline): currently used R407C refrigerant;

- Option 2: HFC R454C;

- Option 3: HC R1270;

- Option 4: HFO R1234yf;

- Option 5: R717 (ammonia).

In table 4 there are shown GWP coefficients of anlysed refrigerants.

In order to compare the refrigerants, it was decided that the operating parameters would be as follows:

- Evaporaton temperature: $-10^{\circ} \mathrm{C}$,

- Condensation temperature: $35^{\circ} \mathrm{C}$,

- Superheating: $5 \mathrm{~K}$

- Subcooling: $5 \mathrm{~K}$ 
Table 5. GWP of the analyzed refrigerants

\begin{tabular}{|c|c|c|}
\hline Option & Refrigerant & GWP \\
\hline 1 & R407C & 1774 \\
\hline 2 & R454C & 146 \\
\hline 3 & R1270 & 2 \\
\hline 4 & R1234yf & 4 \\
\hline 5 & R717 (ammonia) & 0 \\
\hline
\end{tabular}

In the figures 3-7 there are shown cycles of each refrigerant for the indicated operating conditions.

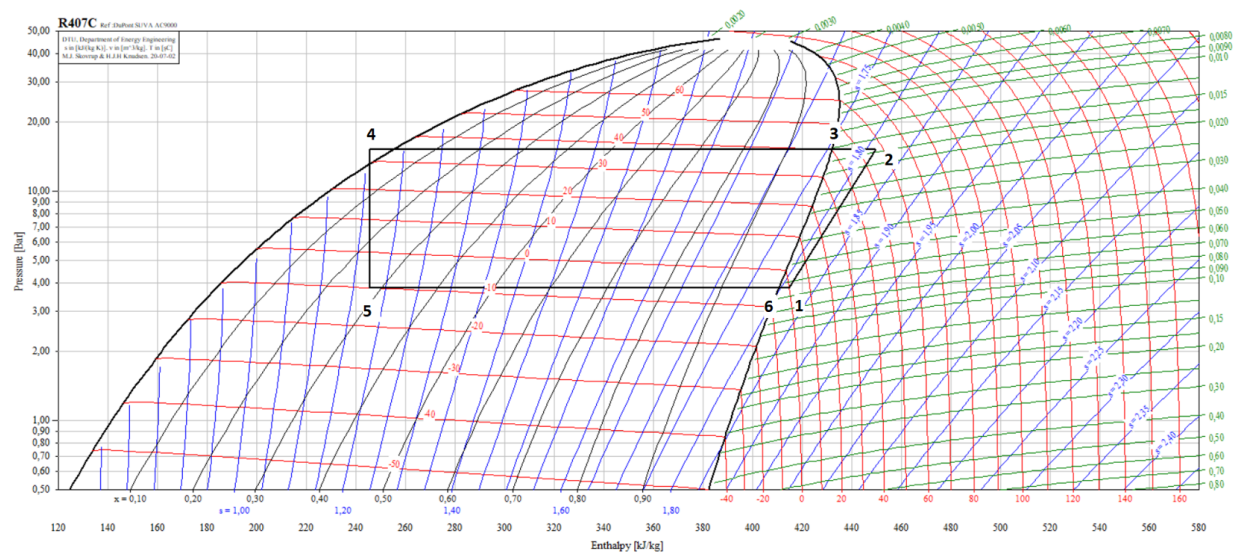

Figure 3. R407C cycle

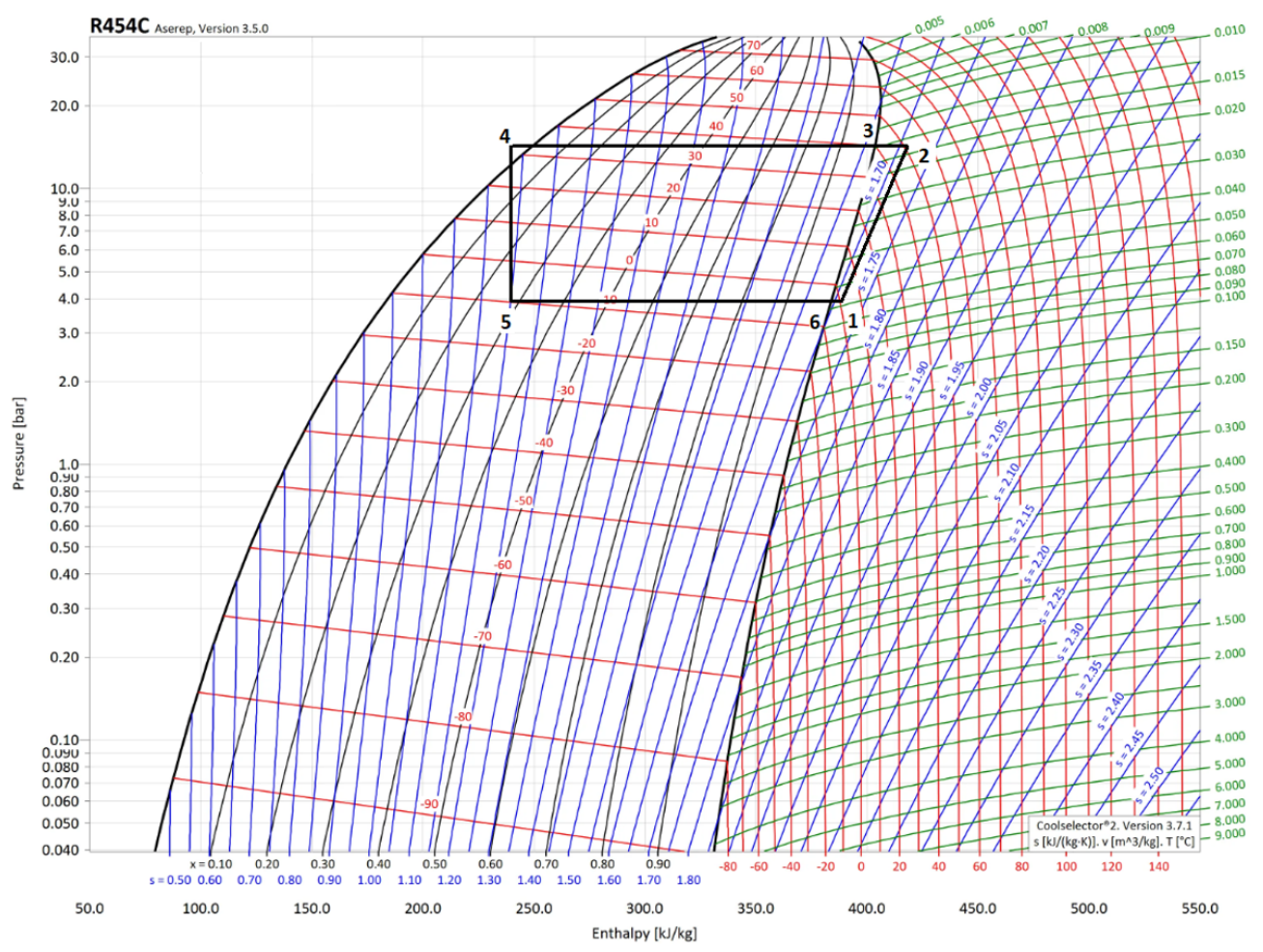

Figure 4. R454C cycle 


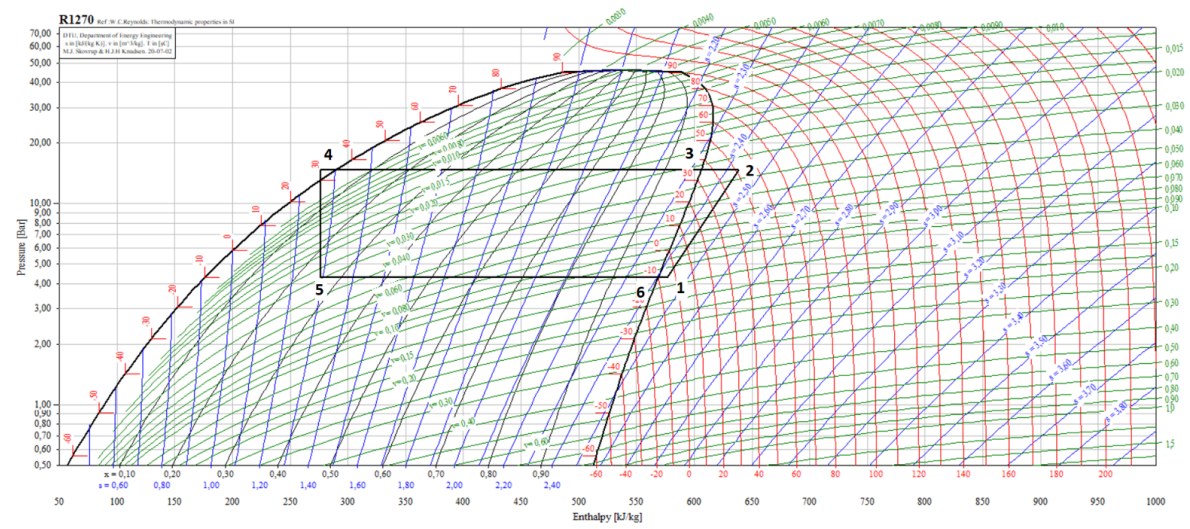

Figure 5. R1270 cycle

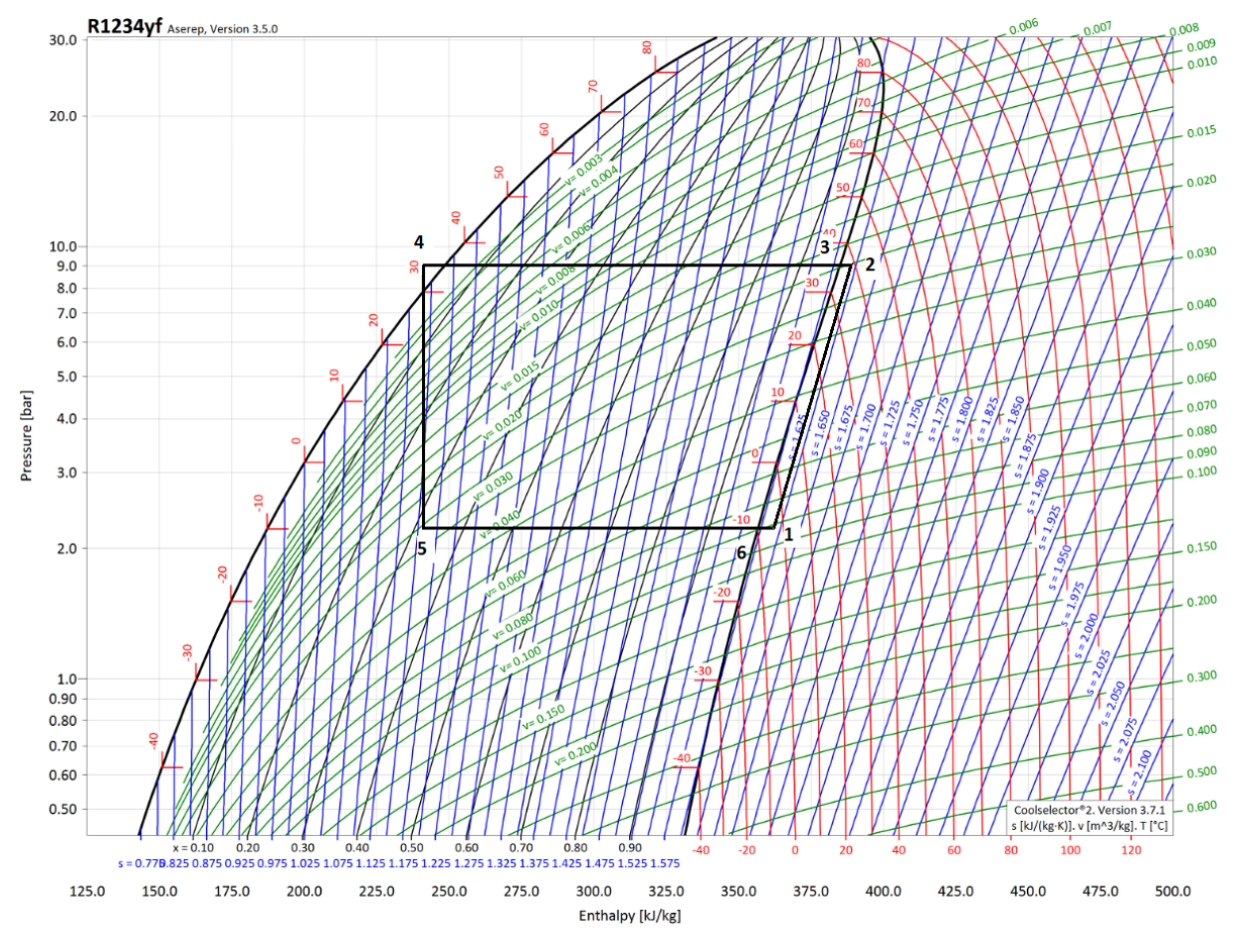

Figure 6. R1234yf cycle

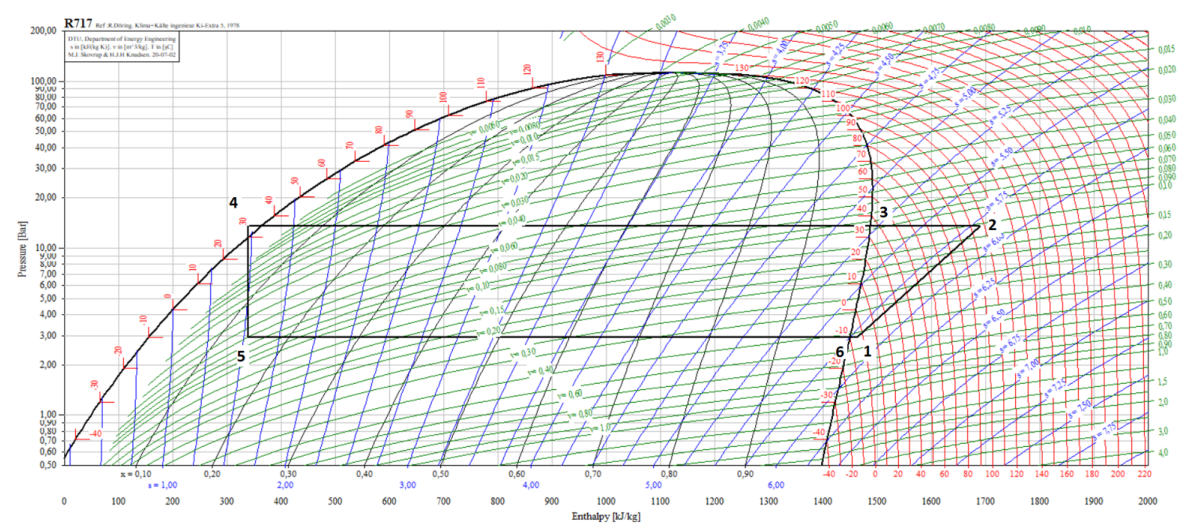

Figure 7. R717 cycle 
The characteristic points of cycles for the analyzed refrigerants are presented in Table 6.

Table 6 . The characteristic points for the analyzed refrigerants

\begin{tabular}{|c|c|c|c|c|}
\hline Refrigerant & point & $\begin{array}{c}\mathrm{T} \\
{\left[{ }^{o} \mathrm{C}\right]}\end{array}$ & $\begin{array}{c}\mathrm{p} \\
{[\mathrm{bar}]}\end{array}$ & $\begin{array}{c}\mathrm{h} \\
{[\mathrm{kJ} / \mathrm{kg} \cdot \mathrm{K}]}\end{array}$ \\
\hline \multirow{6}{*}{$\mathrm{R} 407 \mathrm{C}$} & 1 & 0 & 3.8 & 414.66 \\
\hline & 2 & 57.1 & 15.2 & 449.82 \\
\hline & 3 & 40 & 15.2 & 425.03 \\
\hline & 4 & 35.2 & 15.2 & 245.71 \\
\hline & 5 & -10 & 3.8 & 245.71 \\
\hline & 6 & -5 & 3.8 & 410.14 \\
\hline \multirow{6}{*}{$\mathrm{R} 454 \mathrm{C}$} & 1 & 0 & 3.9 & 390.20 \\
\hline & 2 & 51 & 15.3 & 405.61 \\
\hline & 3 & 40 & 15.3 & 419,45 \\
\hline & 4 & 34.8 & 15.3 & 238.89 \\
\hline & 5 & -10 & 3.9 & 238.89 \\
\hline & 6 & -5 & 3.9 & 383.24 \\
\hline \multirow{6}{*}{$\mathrm{R} 1270$} & 1 & -5 & 4.3 & 576.35 \\
\hline & 2 & 51.5 & 14.7 & 638.71 \\
\hline & 3 & 35 & 14.7 & 606.25 \\
\hline & 4 & 35 & 14.7 & 276.25 \\
\hline & 5 & -10 & 4.3 & 276.25 \\
\hline & 6 & -10 & 4.3 & 568.75 \\
\hline \multirow{6}{*}{ R1234yf } & 1 & -5 & 2.3 & 363.46 \\
\hline & 2 & 39 & 9.1 & 388.46 \\
\hline & 3 & 35 & 9.1 & 384.62 \\
\hline & 4 & 35 & 9.1 & 240.38 \\
\hline & 5 & -10 & 2.3 & 357.69 \\
\hline & 6 & -10 & 2.3 & 357.69 \\
\hline \multirow{6}{*}{$\mathrm{R} 717$} & 1 & -5 & 2.9 & 1461.85 \\
\hline & 2 & 106.9 & 13.5 & 1690.10 \\
\hline & 3 & 35 & 13.5 & 1487.50 \\
\hline & 4 & 35 & 13.5 & 339.04 \\
\hline & 5 & -10 & 2.9 & 339.04 \\
\hline & 6 & -10 & 2.9 & 1450.40 \\
\hline
\end{tabular}

Based on the charts and the determined operating parameters, it can be concluded that both R454c and R1270 (propylene) operate at similar pressures as R407C. In the case of R1234yf, the operating pressure at the relevant points is much lower (by about 30\%). R717 (ammonia) reaches a pressure of about $20 \%$ lower. In addition, it takes the highest temperature after the compressor among other refrigerants, which can be even $107^{\circ} \mathrm{C}$. Using the information 
presented in the charts and in the table, the EER (Energy Efficiency Ratio) for devices operating with appropriate refrigerants were determined. The following relationship was used for the calculations:

$$
E E R=\frac{h_{1}-h_{5}}{h_{2}-h_{1}}
$$

where $\mathrm{h}$ are enthalpy values in specified points. In the Figure 8 and in the Table $\mathrm{t}$ there are shown calculated EER coefficients and their reference to the refrigerant R407C.

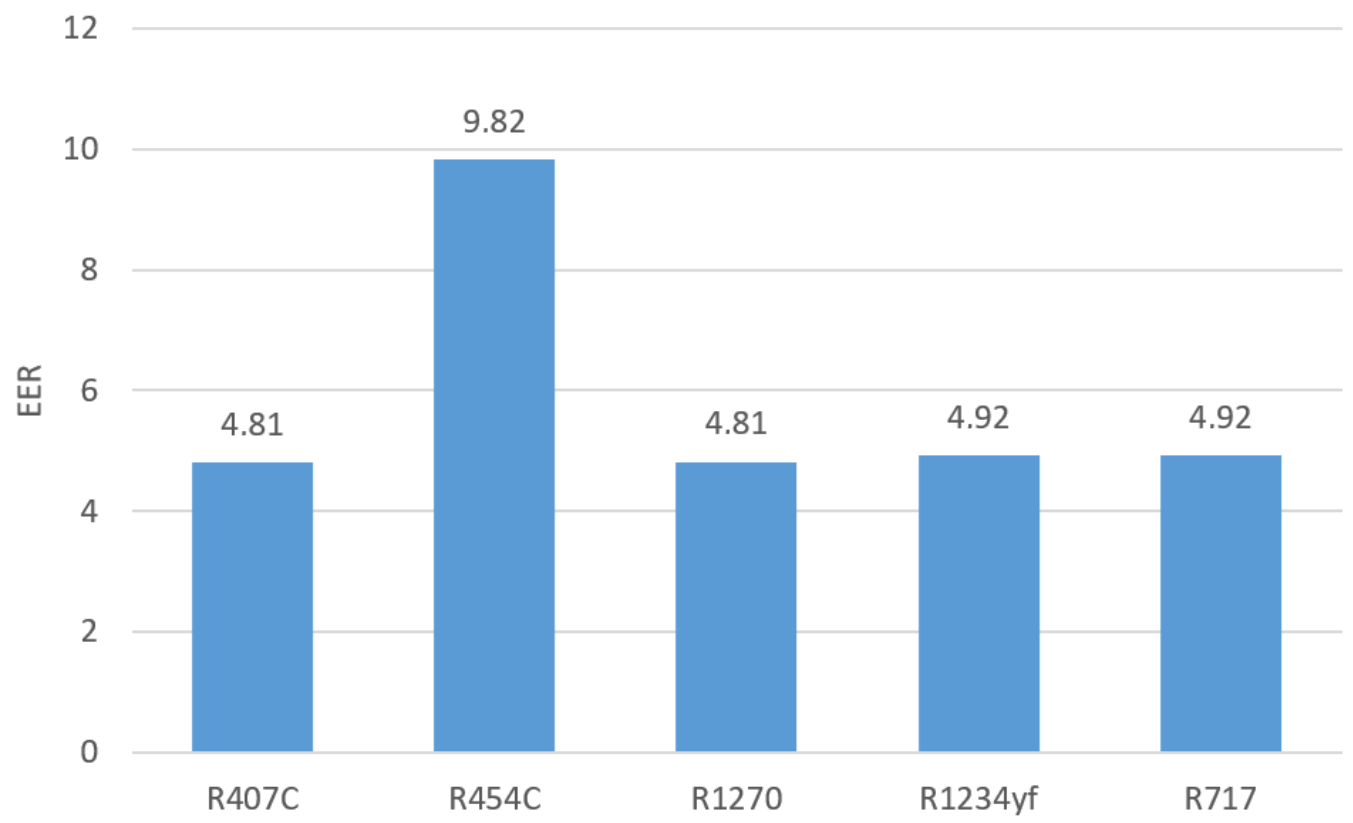

Figure 8. EER value

Table 7. EER value

\begin{tabular}{|c|c|c|c|}
\hline Option & Refrigerant & EER & change [\%] \\
\hline 1 & R407c & 4.805 & 100.00 \\
\hline 2 & R454c & 9.819 & 204.34 \\
\hline 3 & R1270 & 4.812 & 100.15 \\
\hline 4 & R1234yf & 4.923 & 102.46 \\
\hline 5 & R717 & 4.919 & 102.37 \\
\hline
\end{tabular}

In the case of R1270, there is a slight change in EER versus R407C. Refrigerants R1234yf and R717 achieved over $2 \%$ increase in EER during operation for the indicated parameters. The largest increase in cooling capacity (more than two times) was achieved by $\mathrm{R} 454 \mathrm{C}$ and amounted to 9.819 . This suggests a much lower demand for electricity 
during the use of the installation that uses this refrigerant, and thus lower operating costs. It can also be concluded that it would be one of the most effective solutions that could be used.

In the next step of analyzes, the refrigerant mass flow was calculated to obtain the required cooling capacity: 12.31 kW. Calculated values are shown in Figure 9 and table 8.

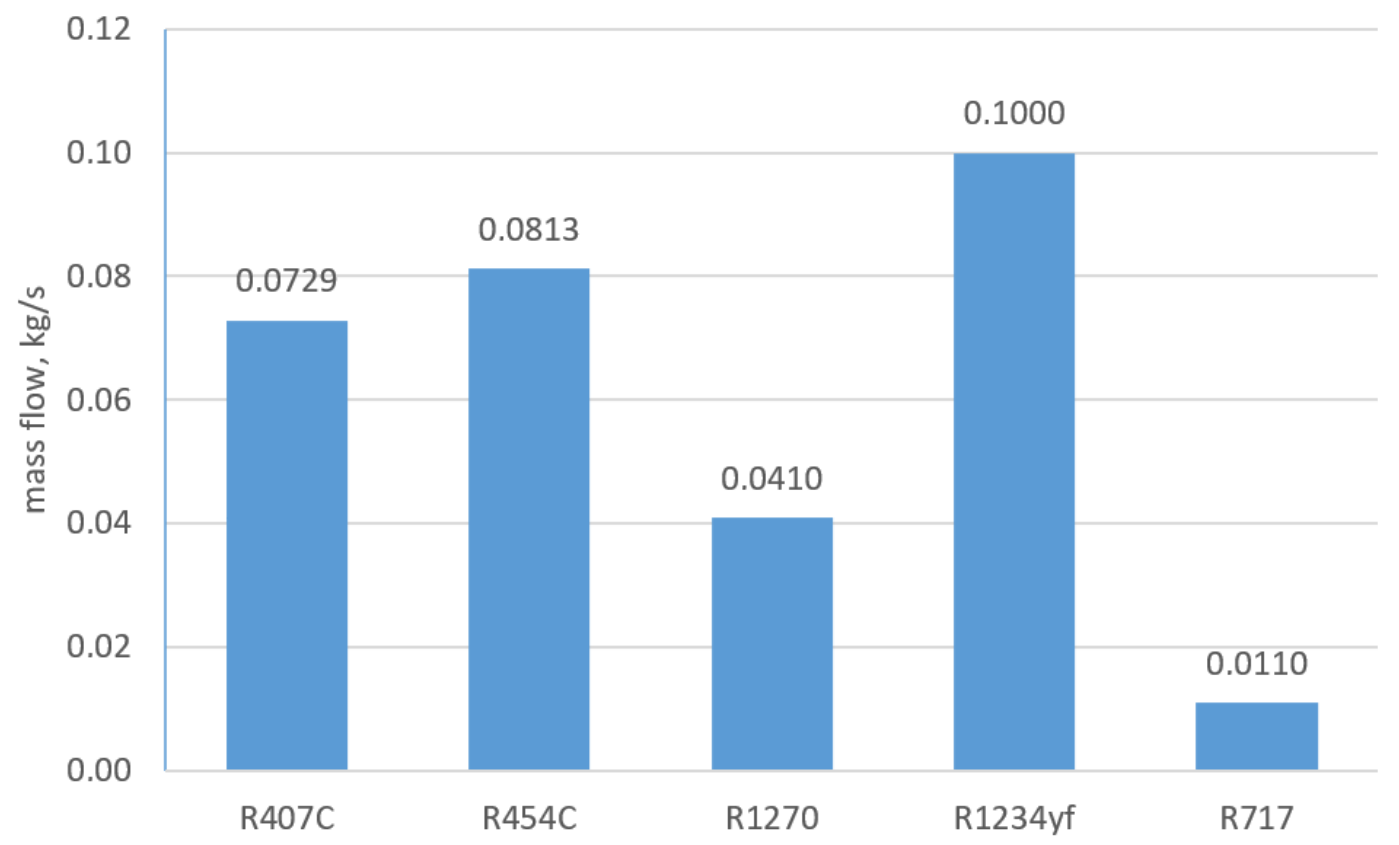

Figure 9. Mass flow of refrigerants for cooling capacity of $12.31 \mathrm{~kW}$

Table 8. Mass flow of refrigerants for cooling capacity of $12.31 \mathrm{~kW}$

\begin{tabular}{|c|c|c|c|}
\hline Option & Refrigerant & Mass flow [kg/s] & change [\%] \\
\hline 1 & R407C & 0.0729 & 100.00 \\
\hline 2 & R454C & 0.0813 & 111.66 \\
\hline 3 & R1270 & 0.0410 & 56.30 \\
\hline 4 & R1234yf & 0.1000 & 137.27 \\
\hline 5 & R717 & 0.0110 & 15.05 \\
\hline
\end{tabular}

The table 8 shows that the use of alternative refrigerants would significantly change their flows through the refrigeration system. In order to maintain the appropriate operating parameters and cooling capacity at the required level, it will involve a change of automation and reconstruction of the installation where necessary, including replacement of the piping system and replacement or adjustment of the compressor operation. 


\section{Conclusions}

As part of the work, the need to reconstruct the refrigeration system operating on the R407C refrigerant so that it could function with a more ecological refrigerant was analyzed. After analyzing four possibilities, the R1234yf and $\mathrm{R} 454 \mathrm{C}$ factors were finally analyzed in detail due to their favorable properties in relation to the analyzed case. It was noted that R1234yf has a negligible impact on the environment, reaching a GWP level of 4 . In the case of R454C the value is much higher (146), but it still complies with the legal regulations in force in the European Union. Comparing the operating parameters of the refrigerants, it was noticed that at the corresponding operating points R454C achieves similar pressures and temperatures as the withdrawn refrigerant R407C (Table 6). On the other hand, the R1234yf refrigerant in relation to $\mathrm{R} 407 \mathrm{C}$ achieves about $30 \%$ lower working pressure at the same points. The EER coefficient of cooling performance of the individual refrigerants was examined. In the case of the R454C, it achieved more than twice the value of the R407C and R1234yf. This gives grounds for the conclusion that it would be able to achieve a much lower demand for electricity during the operation of the installation, and thus would result in lower labor costs. But it must be remembered that the analysis has been carried out for the efficiency of compressors equal to $100 \%$ in real systems this value is from 60 to $80 \%$. Another element of the analyzes was the determination of the flows of substitutes through the potential installation. It resulted in the need to reconstruct the piping system. Obviously, this would be necessary if the required cooling capacity of $12.309 \mathrm{~kW}$ (approx. $12.3 \mathrm{~kW}$ ) were to remain the same. Overall, the use of R1234yf would require more fittings, which would entail higher costs. However, it is a much more ecological refrigerant than R454C. R454C, however, has approximate operating parameters as the reference coolant R407C. In addition, it achieves a much higher EER, which would have a significant impact on the operating costs of the entire installation. It can therefore be concluded that R454C is financially more profitable, while R1234yf is more profitable in terms of environmental impact. It should be remembered that when selecting alternative refrigerants, it is important to take into account their operating parameters, energy efficiency, ease of use, as well as safety and environmental impact. Important elements are also the cost of operating the entire system, its purchase, and the cost and availability of the refrigerant. All these components should form a whole that characterizes the new coolant required for our requirements. Unfortunately, in reality, in the case of media with a low GWP, their flammability increases, while the higher their energy efficiency, the higher their toxicity. There is not yet a refrigerant that meets $100 \%$ of all environmental and economic requirements. Thus, their current use in refrigeration appliances is so far the result of a compromise between their advantages and disadvantages.

\section{References}

1. Bagiński, D. \& Bonca, Z. Dwutlenek węgla jako płyn roboczy na tle innych czynników chłodniczych. Technika chłodnicza i klimatyzacyjna 6-7, 254-262 (2007).

2. Baryłka, A. The impact of fire on changing the strngth of the underground shelter structure. Rynek Energii 146, 71-75 (1 2020).

3. Brak, G., Styrna, A. \& Kącki, P. Akademia R744 (CO2) - wprowadzenie branży w chłodnictwo oparte na dwutlenku węgla. III Warsztaty chłodnicze.

4. Briley, G. C. A History of Refrigeration. ASHRAE Journal, 31-34 (2004).

5. Chen, J., An, B., Yang, L., Wang, J. \& Hu, J. Construction and optimization of the cold storage process based on phase change materials used for liquid air energy storage system. Journal of Energy Storage 41, 102873. ISSN: 2352-152X (2021).

6. Chłodnictwo przemysłowe. Aplikacje z użyciem amoniaku i CO2 Danfoss, 2015.

7. Commercial CO2 Refrigeration Systems Guide for Subcritical and Transcritical CO2 Applications (Emerson Climate Technologies, 2014).

8. Compendium, Everything for CO2 retail applications Carel Industries, 2015.

9. Czynniki chłodnicze - Raport 17 (Bitzer Kühlmaschinenbau GmbH).

10. Deng, Q., Zhang, Z. \& Hu, X. Thermoeconomic and environmental analysis of an inverter cold storage unit charged R448A. Sustainable Energy Technologies and Assessments 45, 101159. ISSN: 2213-1388 (2021).

11. Dziennik Ustaw 2017 poz. 1567 Ustawa z dnia 12 lipca 2017 r. o zmianie ustawy o substancjach zubożajacych warstwę ozonowa oraz o niektórych fluorowanych gazach cieplarnianych oraz niektórych innych ustaw, Warszawa, 23 sierpnia $2017 \mathrm{r}$.

12. F-gazy - Kompendium wiedzy o rozporządzeniu w sprawie F-gazów Mitsubishi Electric, 2018.

13. Fluorowane czynniki chłodnicze Prozon Fundacja Ochrony Klimatu, 2017.

14. Grzebielec, A. Zmiany parametrów pracy urządzenia chłodniczego w wyniku zamiany czynnika R410A na propylen. Aparatura Badawcza i Dydaktyczna 22, 285-290. ISSN: 2392-1765 (4 2017). 
15. Grzebielec, A., Pluta, Z., Ruciński, A. \& Rusowicz, A. Czynniki chłodnicze i nośniki energii (Oficyna Wydawnicza Politechniki Warszawskiej, 2011).

16. Grzebielec, A. \& Rusowicz, A. Kierunki rozwoju syntetycznych czynników chłodniczych w Europie. Polska Energetyka Słoneczna 1-4, 45-49 (2012).

17. Grzebielec, A., Rusowicz, A. \& Szelągowski, A. Zastosowanie czynnika chłodniczego R290 (propan) w instalacjach klimatyzacyjnych typu split w aspekcie bezpieczeństwa przeciwwybuchowego. Zeszyty Naukowe SGSP 61, 107119 (1 2017).

18. Grzebielec, A. New refrigerants used by heat pumps. Modern Engineering 3, 100-106 (2020).

19. Jacob, T. A. \& Fronk, B. M. A heat transfer model to predict superheated and saturated condensation of HFC/HFO refrigerant mixtures. International Journal of Heat and Mass Transfer 170, 120947. ISSN: 0017-9310 (2021).

20. Janin, A. O. Praktyczny przewodnik po stosowaniu przepisów Rozporządzenia F-gazowego w dziedzinie chłodnictwa, klimatyzacji i pomp ciepła. Część 2. Technika chłodnicza i klimatyzacyjna, 188-194 (2015).

21. Jonasson, P. The new F-gas Regulation Challenges RACHP Business on Multiple Fronts. Industria Formazione.

22. Karthikeyan, K., Mariappan, V., Anish, R., Sarafoji, P. \& Jaya Bharata Reddy, M. Experimental study on the charging and discharging behaviour of capric-lauric acid/oleic acid mixture in a cold thermal energy storage system for cold storage applications. Materials Today: Proceedings. ISSN: 2214-7853 (2021).

23. Kożuchowski, K. Meteorologia i klimatologia (Wydawnictwo Naukowe PWN, Warszawa, 2019).

24. Llopis, R. et al. TEWI analysis of a stand-alone refrigeration system using low-GWP fluids with leakage ratio consideration. International Journal of Refrigeration 118, 279-289. ISSN: 0140-7007 (2020).

25. Mackenzie, A., Ball, A. \& Virdee, S. BIOS Instant Notes in Ecology (Taylor and Francis, 2001).

26. Miyauchi, H. et al. Isothermal phase equilibria for the (HFC-32+HFC-134a) mixed-gas hydrate system. The Journal of Chemical Thermodynamics 47, 1-5. ISSN: 0021-9614 (2012).

27. Mizera, G. Nowe trendy w technologii i technice przechowalni warzyw i owoców. Chłodnictwo i Klimatyzacja 4 (2017).

28. Montreal Protocol on substances that deplete the ozone layer

29. Mostafa, A., Hassanain, M. \& Elgendy, E. An experimental study of R-454C pull-down performance as a drop-in refrigerant in a walk-in cold store system. International Journal of Refrigeration. ISSN: 0140-7007 (2021).

30. Mota-Babiloni, A., Haro-Ortuño, J., Navarro-Esbrí, J. \& Ángel Barragán-Cervera. Experimental drop-in replacement of R404A for warm countries using the low GWP mixtures R454C and R455A. International Journal of Refrigeration 91, 136-145. ISSN: 0140-7007 (2018).

31. Oruç, V. \& Devecioğlu, A. G. Experimental investigation on the low-GWP HFC/HFO blends R454A and R454C in a R404A refrigeration system. International Journal of Refrigeration 128, 242-251. ISSN: 0140-7007 (2021).

32. Owczarek, M. \& Baryłka, A. Estimation of thermal diffusivity of building elements based on temperature measurement for periodically changing boundary conditions. Rynek Energii 144, 55-59 (5 2019).

33. Owczarek, M., Owczarek, S., Baryłka, A. \& Grzebielec, A. Measurement Method of Thermal Diffusivity of the Building Wall for Summer and Winter Seasons in Poland. Energies 14. ISSN: 1996-1073 (2021).

34. Pawiłojć, A., Targański, W. \& Bonca, Z. Odzysk ciepła w systemach wentylacyjnych i klimatyzacyjnych (I.P.P.U. MASTA Sp. z o.o., Gdańsk, 1999).

35. Piotrowski, M. CO2 - Technologia i urzadzenia Wrocław: Area Cooling Solutions SP. Z o.o., 2017.

36. Przewodnik po znowelizowanym rozporzadzeniu Parlamentu Europejskiego i Rady (EU) nr 517/2014 w sprawie fluorowanych gazów cieplarnianych Linde, 2014.

37. Przyspiesz zmiane czynnika chłodniczego i chroń klimat, Czynniki chłodnicze o niskim GWP Danfoss, 2019.

38. REGULATION (EC) No 1005/2009 OF THE EUROPEAN PARLIAMENT AND OF THE COUNCIL of 16 September 2009 on substances that deplete the ozone layer

39. Regulation (EU) No 517/2014 of the European Parliament and of the Council of 16 April 2014 on fluorinated greenhouse gases and repealing Regulation (EC) No 842/2006

40. Targański, W. Alternatywne syntetyczne czynniki chłodnicze. Chłodnictwo i Klimatyzacja 1-2 (2016).

41. Tryjanowski, M., Mazurkiewicz, P. \& Ratajczak, W. Praktyczne aspekty w projektowaniu instalacji chłodniczych w supermarketach. Chłodnictwo i Klimatyzacja 8 (2018).

42. VDI 2052, Raumlufttechnische Anlagen für Küchen (Ventilation equipment for kitchens) Düsseldorf: Verein Deutscher Ingenieure, 2006.

43. Vienna Convention for the Protection of the Ozone Layer 1988.

44. Yang, Z. et al. Analysis of lower GWP and flammable alternative refrigerants. International Journal of Refrigeration 126, 12-22. ISSN: 0140-7007 (2021). 
45. Yu, M., Fan, Y., Zhang, C., Zhang, X. \& Zhao, Y. Simulation study on performance of an air source heat pump system combined with phase change thermal storage using alternative refrigerants. International Journal of Refrigeration 125, 13-24. ISSN: 0140-7007 (2021). 